\title{
Effects of Active Learning and FGD Education Methods on the DAGUSIBU Knowledge of MA Nurul Ummah Students, Yogyakarta
}

\author{
Susan Fitria Candradewi ${ }^{1, *}$ Ginanjar Zukhruf Saputri ${ }^{2}$ Dwi Sundari ${ }^{3}$ Iska Azkah Azizah ${ }^{4}$
}

1,2,3,4 Faculty of Pharmacy, Universitas Ahmad Dahlan

*Corresponding author.Email: susan.candradewi@pharm.uad.ac.id

\begin{abstract}
A research on drugs administration in Manado in 2014 revealed that $44.77 \%$ of the local population did not procure drugs properly, $75.9 \%$ received the wrong ones, $25.3 \%$ did not store them as suggested, and $72 \%$ did not use them appropriately. As an attempt to avoid medication management mistakes in the community, the Indonesian Pharmacist Association has introduced a program termed DAGUSIBU, an abbreviated form of 'to get, use, store, and discard'. DAGUSIBU contains information on the procedures to receive, use, store, and dispose drugs correctly; hence, immediate dissemination or education is highly suggested. High school students were involved as the main cadre in the research because adolescents are at the age of rapid physical and mental development and, thereby, the most vulnerable age group to misinformation. This study was set out to determine the effects of DAGUSIBU education on the knowledge of MA Nurul Ummah students in Yogyakarta. This experimental study involved pharmacists in providing education using the active learning method (CBIA) and focus group discussion (FGD). Student's knowledge of DAGUSIBU was assessed before and after the education using a validated questionnaire. Meanwhile, differences between the students' knowledge pre- and post-education were quantified using a paired sample t-test in the SPSS v.16 program. The results indicated that on the average, the students' knowledge level increased after receiving education on DAGUSIBU. Through the active learning method (CBIA), the rate of knowledge level nearly doubled from $4.2923 \pm 1.54$ (pre) to $7.9231 \pm 1.04$ (post) $(\mathrm{p}=0.000)$, and after the FGD, it also increased from $5.1333 \pm 1.89$ to 7.0167 \pm 1.03 ( $\mathrm{p}=0.000$ ). CBIA method is proven to be more effective in enhancing knowledge regarding DAGUSIBU compared to FGD method with $\mathrm{p}$ value $=0.007$. In conclusion, there are significant differences in the knowledge of DAGUSIBU among the students of MA Nurul Ummah after receiving this education through active learning (CBIA) and FGD methods.
\end{abstract}

Keywords: DAGUSIBU, knowledge, active learning, CBIA, FG

\section{INTRODUCTION}

Self-medication is the most common way to overcome any indications or symptoms before people seek help to healthcare center/medical staff. ${ }^{1}$ The data of National Social Economy Survey in 2014 showed that the percentage of citizens doing self-medication for health symptoms endured was $61.05 \% .^{2}$

According to the research employed by Harahap (2017), self-medication practice may lead to medication mistakes, such as inappropriate drug selection and inappropriate drug use $(18.7 \%)$. Mistakes in self-medication are mostly caused by inappropriate use of drug dosage (34.5\%). ${ }^{3}$ Another research employed by Tuarissa showed that 169 patients out of 306 patients obtained drugs properly, which means that $44.77 \%$ people obtained drugs improperly. ${ }^{2}$ Raini ${ }^{3}$ conveyed that $75.9 \%$ people obtained drugs in a wrong way for mild use drugs, $25.3 \%$ misplaced the drugs, and $72 \%$ had inappropriate drug use.

Based on the commonplace medication mistakes in the community, Indonesian Pharmacist Association created a program to enhance people's understanding on drugs use. The program aims to reduce inappropriate risks in self-medication practices by providing the community with one basic information related to the good and correct knowledge of the way to get, use, keep, and dispose drugs (DAGUSIBU).

Dagusibu is a term introduced by Indonesian Pharmacist Association that serves as one of the programs of Family's Drugs Awareness move based on Act No. 36 Year 2009. This act aims to provide information to the community about the good and correct way to get, use, keep, and discard drugs and to enhance people's understanding on drugs. ${ }^{6}$ The knowledge of Dagusibu must be provided early to prevent the spread of wrong information, especially for the young generation, adolescents aged 15-18 years old (Abhitama, et.al, 2019). Adolescents experience a rapid physical and mental growth and mental adjustment process of value and attitude development (Hurlock, 1999).

Many Senior High School Students (SMA) practice selfmedication despite the fact that they do not possess adequate knowledge on drugs. The high inappropriateness of drugs use in teenagers occurs as an implication of lack information and knowledge of drugs use, especially for Over-the-CounterDrugs (OTC) or drugs that can be consumed without a doctor's prescription. Hence, every medical staff is liable to provide Communication, Information, and Education (KIE) to the community. ${ }^{4}$ The study aims to reveal the knowledge 
differences among students before and after the education provision on Dagusibu, and find out the effectiveness of the education method to enhance the knowledge of Dagusibu.

\section{METHODS}

This research employed Quasi Experimental design method. This research was included in quasi experimental research because there was no randomization in this research. Therefore, this research compared the influence on the provision of Dagusibu education employing CBIA (Self Active Learning Way) and FGD (Forum Group Discussion).

CBIA (Self Active Learning Way) method was an education model employing students' active participation, while $F G D$ (Forum Group Discussion) was an education method done by dividing students into three groups, which would be supervised by one Pharmacist. This research has obtained an ethical approval license from the Ethics Committee of Ahmad Dahlan University No. 011912113.

The research procedures were as follows:

a. Respondent Selection comprised the students of MA Nurul Ummah Yogyakarta grade X and XI. Grade X obtained Dagusibu education with FGD method, while grade XI obtained the education with CBIA method.

b. Observation of students' knowledge level of Dagusibu through a pre-test using a questionnaire on Dagusibu knowledge that had been validated by Sundari (2020). ${ }^{5}$

c. The delivery of Dagusibu knowledge using 2 different methods: FGD and CBIA.

d. Post-test to measure students' knowledge after the education delivery using the same questionnaire.

\subsection{Tools and Materials}

This research used a validated questionnaire as a research tool based on the previous research on the same topic. ${ }^{8}$ The materials employed in this research were some leaflets containing the PPT explanation of DAGUSIBU, activity instruction, drugs sheet and drugs package consisting 3 kinds of drugs with different therapy classes, which were antipyretic analgesic, flu drug, and intestinal drugs.

\subsection{Research Population and Samples}

The research population was the entire students of Madrasah Nurul Ummah Yogyakarta, and the sample was the students of Madrasah Nurul Ummah grade X and XII who met the requirements criteria of inclusion and exclusion. The inclusion criteria in this research were students who had used drugs with or without prescription, and those who could read and write. The exclusion criteria in this research were samples who were unwilling to join the whole education stages, unable to come, and did not complete to questionnaire. The sampling method in this research was done by purposive sampling, which meant that research sample had been determined based on certain requirements that fulfilled the inclusion and exclusion research criteria.

\subsection{Education Method}

\subsubsection{Education Procedures employing FGD method}

Respondents were divided into 3 groups with 1 spokesperson for every group with 20 students as the respondents, (2) Respondents were given a leaflet on Dagusibu to read for 15 minutes, (3) Respondents were given material on Dagusibu to learn for 30 minutes, (4) Question and Answer discussion was held on the material that had been delivered.

\subsubsection{Education Procedures employing CBIA method}

Respondents would get the introduction material on Dagusibu delivered by a pharmacist employing the PPT presentation method for 45 minutes, (2) Respondents were divided into 8 groups with 6-8 members (3) Then, every group would receive a package of drugs to be observed: its brand, its ingredients with its strength, and its main and additional ingredients in each drug. Afterwards, every group would organize the drugs based on the kinds of active ingredients and discuss the observation results of the activity with the direction of the group leader. In this stage, every group would be guided by a tutor ( $7^{\text {th }}$ semester pharmacy student), (4) The fourth-stage-activity was collecting information needed as the basis for doing self-medication and taking drugs, (5) Pleno discussion led by a moderator was held. Every group was asked to explain their experiences and important findings during the group discussion. After that, the moderator would summarize the important findings and tell the respondents to spread the knowledge of Dagusibu obtained in the CBIA activity.

\subsection{Research Population and Samples}

The data analysis in this research was done using univariate and bivariate analysis. The univariate analysis was selected to find out the description of the sample characteristics based on age, sex, parents' occupation, and the distance of the house to the pharmacy. The bivariate analysis in this research employed different tests on paired sample t test to discover the different level of knowledge of each group before and after the education delivery, and independent sample $t$ test to find out the different level of knowledge between the two groups before and after the education.

\section{RESULT AND DISCUSSION}

\subsection{Research Result}

This research was done at Madrasah Nurul Ummah Yogyakarta in March 2020, with a total research sample of 125 students divided into two groups, each of which receiving two education methods, which were CBIA (Self Active Learning Way) for 65 students and FGD (Group Discussion Forum) for 60 students. Table 1 shows the respondents' demography containing sex, age, parents' occupation and the 
distance of the house to the drugstore. The distribution of respondents' demography in these two groups showed that there was not any meaningful difference statistically ( $>0,005$ ). In addition, it also showed that the respondents' demography characteristics in the two groups were equal. The basic characteristic differences of the two groups had to be revealed to make sure that each respondent in the two education methods groups was in the similar level. The description of respondents' demography, which was based on sex in both of FGD and CBIA method groups, showed that most respondents were female mostly of 15 and 16 years old.

Table 1. Demography Distribution of Students at MA Nurul Ummah Yogyakarta Based on Sex, Age, Parents' Occupation, and the Distance of the House to the Drugstore

\begin{tabular}{|c|c|c|c|c|}
\hline \multirow{2}{*}{\multicolumn{2}{|c|}{ Variable }} & \multicolumn{2}{|c|}{ Percentage (\%) } & \multirow[t]{2}{*}{ P-value } \\
\hline & & FGD $(n=60)$ & CBIA $(n=65)$ & \\
\hline \multirow[t]{3}{*}{1.} & Sex & & & \multirow{3}{*}{0.704} \\
\hline & a. Male & $38 \%$ & $46 \%$ & \\
\hline & b. Female & $62 \%$ & $54 \%$ & \\
\hline \multirow[t]{6}{*}{2.} & Age & & & \multirow{6}{*}{0.824} \\
\hline & a. 15 years old & $62 \%$ & - & \\
\hline & b. 16 years old & $33 \%$ & $49 \%$ & \\
\hline & c. 17 years old & $5 \%$ & $38 \%$ & \\
\hline & d. 18 years old & - & $11 \%$ & \\
\hline & e. 19 years old & - & $2 \%$ & \\
\hline \multirow[t]{6}{*}{3.} & Parents' Occupation & & & \multirow{6}{*}{0.575} \\
\hline & a. Civil Servant & $17 \%$ & $22 \%$ & \\
\hline & b. Farmer & $30 \%$ & $25 \%$ & \\
\hline & c. Labor & $8 \%$ & $2 \%$ & \\
\hline & d. Enterpreneur & $40 \%$ & $35 \%$ & \\
\hline & e. Civil Officer & $5 \%$ & $17 \%$ & \\
\hline \multirow[t]{5}{*}{4.} & Distance of the house to the drugstore & & & \multirow{5}{*}{0.812} \\
\hline & a. Less than $1 \mathrm{~km}$ & 40 & 55 & \\
\hline & b. $1-5 \mathrm{~km}$ & 43 & 23 & \\
\hline & c. $6-9 \mathrm{~km}$ & 2 & 6 & \\
\hline & d. More than $9 \mathrm{~km}$ & 15 & 15 & \\
\hline
\end{tabular}

Table 2. presents factual questions from research samples to notice the practice of self-medication among respondents. Most of respondents preferred self-medication when they were ill as indicated by the result of question no. 1 that most students would buy drugs at the pharmacy when they were ill. Students mostly considered the pharmacist's recommendation in selecting drugs for self-medication as indicated by the rate of $25 \%$ in FGD group and $31 \%$ in CBIA group. Majority of the respondents (98\% and 96\%) said that they already knew how to use drugs and most of them said that the information regarding the rules for taking medicines were obtained from the instructions in the medicine label or drug brochure (35\% and $38 \%)$.

Table 2. Students' Self-Medication Practice at MA Nurul Ummah Yogyakarta

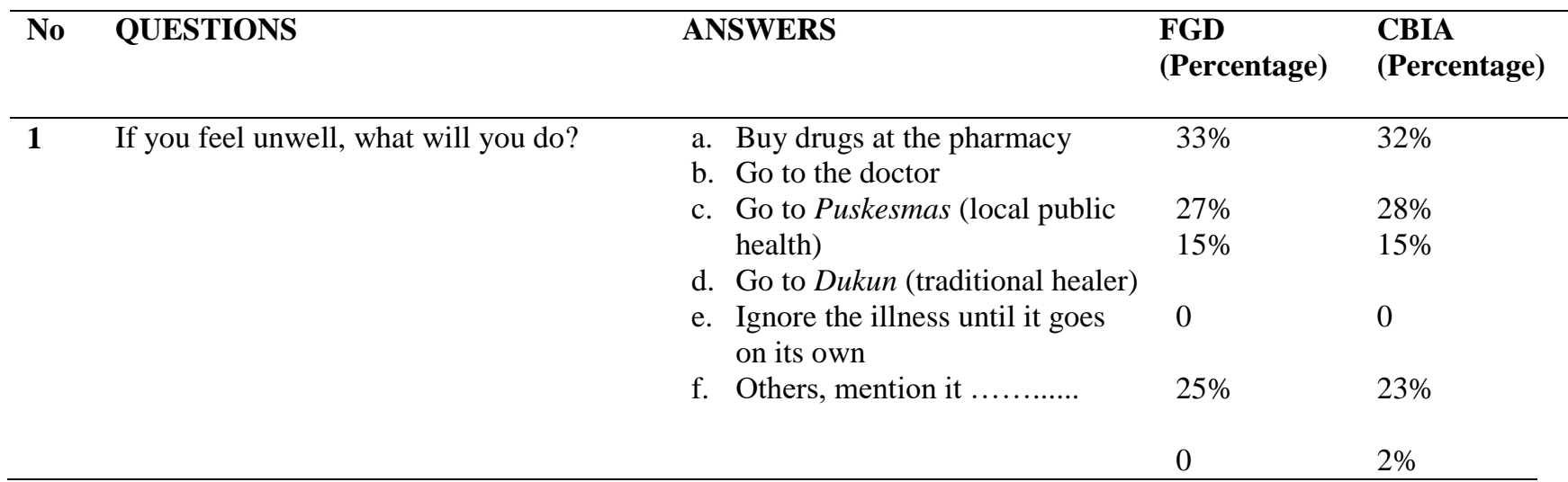


2 If you do self-medication, which type of drugs will you take?

a. Over the counter drugs $\quad 60 \%$

b. Free restricted drugs

c. Traditional drugs/herbs $\quad 18 \%$

d. Others, mention it

3 If you practice self-medication, what will

$0 \%$ you consider in selecting the drugs?

b. TV's advertisement suggestion $0 \%$

c. Information from printed media $17 \%$

d. Based on experience

e. Pharmacist's recommendation $18 \%$

$0 \%$

f. Doctor's recommendation

g. Others, mention it

4 Where do you obtain the drugs from?
a. Pharmacy
b. Drugstore
c. Small shop
d. Doctor
e. Hospital
f. Puskesmas (local public health)

$55 \%$

$68 \%$

$8 \%$

$20 \%$

$4 \%$

0

$8 \%$

$17 \%$

$3 \%$

0

5 Do you know how to use the drug?
a. Yes
$98 \%$
$94 \%$

b. No

$2 \%$

$6 \%$

6 If you know the direction to use the drug,

a. From medical staff

$20 \%$

$48 \%$ where do you get the information from?
b. From friends/relatives/
neighbours
c. From medicine
labels/brochure
d. From advertisements
e. Others

$32 \%$

$14 \%$

$\begin{array}{ll}8 \% & 0 \\ 5 \% & 0\end{array}$

7 What do you read on the medicine label/drug brochure?
a. Drug's name
b. indication/ direction
c. Dosage
d. Side effects
e. Warning and cautions

$15 \%$

0

$32 \%$

$15 \%$

f. Others, mention it

Table 3. DAGUSIBU Knowledge Level of Students at MA Nurul Ummah Yogyakarta

\begin{tabular}{llll}
\hline \multirow{2}{*}{ Education Method } & \multirow{2}{*}{ Knowledge Level } & \multicolumn{2}{l}{ Students' Percentage (\%) } \\
\cline { 3 - 4 } & & Pre-test & Post-test \\
\hline Forum Group Discussion & Good & $25 \%$ & $\mathbf{7 3 \%}$ \\
& Enough & $18 \%$ & $\mathbf{2 2 \%}$ \\
& Less than average & $57 \%$ & $\mathbf{5 \%}$ \\
\hline \multirow{2}{*}{ CBIA (Self Active Learning } & Good & $\mathbf{9 , 2 3 \%}$ & $\mathbf{7 6 , 9 2 \%}$ \\
Way) & Enough & $\mathbf{4 3 , 0 8 \%}$ & $\mathbf{2 1 , 5 4 \%}$ \\
& Less than average & $\mathbf{4 7 , 6 9 \%}$ & $\mathbf{1 , 5 4 \%}$ \\
\hline
\end{tabular}


Table 4. The Effectiveness of The FGD and CBIA Methods In Increasing DAGUSIBU Knowledge of Students At MA Nurul Ummah Yogyakarta

\begin{tabular}{|c|c|c|c|c|c|}
\hline \multirow{2}{*}{ Education Method } & \multicolumn{2}{|c|}{$\begin{array}{l}\text { Average Knowledge Score } \\
(\bar{X} \pm \mathrm{SD})\end{array}$} & \multirow{2}{*}{$\begin{array}{l}\text { p-value pre- } \\
\text { post test }\end{array}$} & \multirow{2}{*}{$\begin{array}{l}\text { p-value pre- } \\
\text { test between } \\
\text { groups }\end{array}$} & \multirow{2}{*}{$\begin{array}{l}\text { p-value post- } \\
\text { test between } \\
\text { groups }\end{array}$} \\
\hline & Pre-test & Post-test & & & \\
\hline Group Discussion Forum & $5.1333 \pm 1.89$ & $7.0167 \pm 1,03$ & $0.000^{\mathrm{a}^{*}}$ & \multirow[b]{2}{*}{$0.07^{\mathrm{b}}$} & \multirow[b]{2}{*}{$0.000^{\mathrm{b} *}$} \\
\hline $\begin{array}{l}C B I A \text { (Self Active Learning } \\
\text { Way) }\end{array}$ & $4.2923 \pm 1.54$ & $7.9231 \pm 1.04$ & $0.000^{\mathrm{a}^{*}}$ & & \\
\hline
\end{tabular}

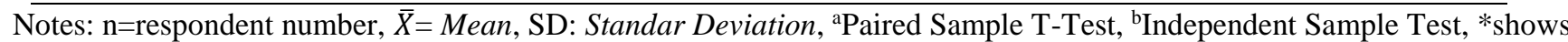
meaningful different significance value

\subsection{Discussion}

Most of respondents, both those grouped in FGD group and those in CBIA group, were adolescents between the age of 15-19 years old. According to the Indonesian Ministry of Education and Culture, most Senior High School students are those aged 16-18 years old. ${ }^{9}$ WHO classifies teenagers as those who are 10 to 19 years old (WHO, 2018). According to Notoatmojo, teenagers mostly have good thinking pattern and the ability to absorb materials, so that education given to teenagers can enhance their knowledge. ${ }^{7}$ The knowledge level during the productive age is better than that in the elderly age because in this productive age, people develop their knowledge, and they possess good five senses that function well, therefore they can absorb information much better as well. ${ }^{8}$

Parents' occupation on both groups are mostly entrepreneurs. Parents' occupation influences the knowledge and the results of the learning process of the Senior High School students. Parents with relatively high income will influence their support and attention to the details of their children's education. ${ }^{9}$ Moreover, the parents' occupation can influence the students' knowledge. ${ }^{10}$ The research by Suleman indicates that students coming from good social-economy have high level of academic knowledge. On the contrary, students coming from deprived social economy have worse academic knowledge. ${ }^{10}$

Respondents' habitual behavior during sickness is mostly indicated by the practice of self-medication. According to the National Socio-Economy Survey Data (Susenas) of 2014 , the percentage of self-medication practice of the community due to emerging health indications was $61.05 \% .{ }^{11}$ The community's preference in determining selfmedication was influenced by several factors, including product advertisements, medication experience, psychological conditions, education, and education background. ${ }^{12}$ Most respondents conveyed that they considered the pharmacist's recommendation when selecting drugs. Thus, it became a challenge for a pharmacist to maximize the practice of Pharmaceutical Care to patients doing self-medication. ${ }^{13}$ Most respondents were well aware of the instructions for use of drugs. In line with the study by Candradewi (2017), most of pharmacy customers $(72 \%)$ noticed the drug use instructions because of the possibility of buying the same drugs for several times for the same indications or because they read the medicine label of the same drug package. ${ }^{14}$

According to Arikunto, the knowledge level can be classified into three categories based on questionnaire score result, namely good ( $\geq 76 \%$ ), good enough, and not good enough if the questionnaire result score is less than $55 \% .^{15}$ The research showed that before the education delivery on both groups, the DAGUSIBU knowledge level of students at MA Nurul Ummah Yogyakarta were mostly less than average. On the contrary, after the education delivery for both groups, it was revealed that most students at MA Nurul Ummah Yogyakarta had high knowledge level, with $73 \%$ and $76.92 \%$ (table 3 ). This result indicates that the education delivery can enhance the students' knowledge level. The result of this research is in line with a research by Suci (2019) highlighting that education delivery with $C B I A$ method has an impacton the community's knowledge of $D A G U S I B U .^{16}$

The knowledge average score before and after the education on both groups demonstrates the significant differences $(\mathrm{p}<0.05)$. The average value scores on the education delivery employing $F G D$ are $5.1333 \pm 1.89$ dan $7.0167 \pm 1.03$ with significance value of $p=0,000$. The education method employing $C B I A$ indicates result that is not too different from the knowledge average score before and after, that is $4.2923 \pm 1.54$ and $7.9231 \pm 1.04$ with significance value of $\mathrm{p}=0.000$. In accordance with the previous research employed by Musdalipah (2018), the students' knowledge of SMA Negri 1 Kendari on $D A G U S I B U$ improved after the education delivery employing Self Active Learning Way with $p$ value of 0.026 $(<0.05){ }^{4}$

Knowledge, attitude, and action towards drug information are some indications of health behaviour. ${ }^{17}$ Therefore, it is important to have a good and correct knowledge on DAGUSIBU as a way to support proper behaviour in practicing self-medication to enhance health quality and creates high quality health standard for the community.

CBIA (Self Active Learning Way) is a student's empowerment education model to improve students' smart ability in selecting drug to allow a more effective, safe, and 
economical self-medication practice. This method is also an intervention of education method adopted from the school learning method of Student's Active Learning Way (CBSA). ${ }^{4}$ Education employing CBIA method makes respondents become more critical in reading the medicine label as a way to enhance the knowledge of the drug to consume, and consequently, the respondents will develop better practice in using drugs. The provision of drug education will enhance knowledge, awareness, and skill of the patients and family in improving their health. ${ }^{7}$

The knowledge average score after the education delivery using group discussion forum $(F G D$ ) and CBIA (Self Active Learning Way) indicates test result significance of $\mathrm{p}=$ 0.000 . In other words, there is a meaningful difference on knowledge average score after the education delivery using the FGD compared to CBIA methods (table 4). It showed that CBIA method was more effective than FGD in enhancing the knowledge of Dagusibu. The result of the study was different from that done by Lathifah entitled "CBIA and FGD methods Comparison in Enhancing Knowledge and Appropriateness of Caregiver in Practicing Self-Medication on Kids' Fever." The result of this study demonstrated that there was no meaningful difference in CBIA and FGD methods in enhancing knowledge and appropriateness in fever self-medication on kids.

\section{CONCLUSION}

In conclusion, there are significant differences in the knowledge of DAGUSIBU among the students of MA Nurul Ummah after receiving this education through active learning (CBIA) and FGD methods. The education delivery in this research can enhance the knowledge of DAGUSIBU on the two method groups with $p$ value of $<0.05$. CBIA method is more effective than FGD method in the provision of DAGUSIBU education with the significance $\mathrm{p}$ value of $<0.0$.

\section{REFERENCES}

[1] Depkes RI. Materi Pelatihan Peningkatan Pengetahuan dan Keterampilan Memilih Obat Bagi Tenaga Kesehatan. Jakarta: Depkes RI; 2008.

[2] Tuarissa S. Profil Penggunaan Obat Klorfeniramin Maleat pada Masyarakat di Kelurahan Bailang dan Kelurahan Karombasan Kota Manado. Pharmacon. 2014;3(4). doi:10.35799/PHA.3.2014.6042

[3] Raini M, Isnawati A. Profil Obat Diare yang Disimpan di Rumah Tangga di Indonesia Tahun 2013. Media Penelit dan Pengembangan Kesehatan. 2016;26(4):227-234. doi:10.22435/mpk.v26i4.4704.227-234

[4] Musdalipah, Daud NS, Fauziah Y, Karmilah. Peningkatan Pengetahuan Siswa SMA Negeri 1 Kendari Tentang Swamedikasi Dengan Metode CBIA (Cara Belajar Insan Aktif). J Masy Merdeka. 2018;1(1):14-20.
[5] Sundari D. Pengaruh Edukasi Terhadap Tingkat Pengetahuan Tentang Dagusibu Pada Siswa SMA Kelas X di MA Nurul Ummah Yogyakarta. 2020.

[6] WHO. Adolescents: Health Risks and Solutions. https://www.who.int/news-room/factsheets/detail/adolescents-health-risks-and-solutions. Published 2018. Retrieved on August 26, 2020.

[7] Notoatmodjo S. Promosi Kesehatan dan Perilaku Kesehatan,. Jakarta: Rineka Cipta; 2014.

[8] Kotler P. Manajemen Pemasaran. Edisi Kesepuluh.; 2006.

[9] Sari R. Hubungan Pendapatan Orang Tua Siswa dengan Hasil Belajar IPS di SDN Gugus 4 Sukowati Kabupaten Sragen. 2016:53.

[10] Suleman Q, Hussain I, Nisa Z-. Effects of Parental Socioeconomic Status on the Academic Achievement of Secondary School Students in District Karak (Pakistan). Int J Hum Resour Stud. 2014;2(4):14. doi:10.5296/ijhrs.v2i4.2511

[11] BPS. Persentase Penduduk yang Mempunyai Keluhan Kesehatan dan Mengobati Sendiri Menurut Provinsi, Daerah Tempat Tinggal, dan Jenis Kelamin. Jakarta; 2018.

[12] Tuanahope N. Peningkatan Pengetahuan Masyarakat Dalam Memilih Obat Bebas Dan Bebas Terbatas Di Rt 005 Kelurahan Oetete Kota Kupang Dengan Metode Cara Belajar Insan Aktif (Cbia). 2018.

[13] Widayati A. Swamedikasi di Kalangan Masyarakat Perkotaan di Kota Yogyakarta (Self-Medication among Urban Population in Yogyakarta). J Farm Klin Indones. 2013;2(4):145-152. https://repository.usd.ac.id/8909/1/Naskah_Swame dikasi Di Kalangan Masyarakat Perkotaan_2013.pdf.

[14] Candradewi SF, Kristina SA. Gambaran Pelaksanaan Swamedikasi dan Pendapat Konsumen Apotek Mengenai Konseling Obat tanpa Resep di Wilayah Bantul. Pharmaciana. 2017;7(1):41. doi:10.12928/pharmaciana.v7i1.5193

[15] Arikunto. Prosedur Penelitian Suatu Pendekatan Praktik,. Jakarta: Rineka Cipta; 2013.

[16] Suci. Perbedaan Pengetahuan Dagusibu Pada Kader PKK Kelurahan Muja Muju Yang Mendapatkan Edukasi dengan Metode Cara Belajar Insan Aktif (Cbia). 2019.

[17] Pratiwi H, Nuryanti N, Fera VV, Warsinah W, Sholihat NK. Pengaruh Edukasi Terhadap Pengetahuan, Sikap, dan Kemampuan Berkomunikasi atas Informasi Obat. Kartika J Ilm Farm. 2016;4(1):10-15. doi:10.26874/kjif.v4i1.51 